\title{
ODGOJ ZA MEDIJE U HRVATSKOM \\ OBRAZOVNOM SUSTAVU
}

\author{
Anamarija Bašić \\ Filozofski fakultet u Splitu \\ Odsjek za povijest \\ anamarija.basic@gmail.com \\ Stručni rad \\ Primljeno: 28. 2. 2019. \\ Prihvaćeno: 29. 10. 2019.
}

\begin{abstract}
U ovom radu tematizira se pojam medija te primjeri pozitivne prakse njihova upotrebljavanja u nastavi Hrvatskoga jezika i Povijesti kao nastavnih sredstava i pomagala. Daje se pregled nastavnih sadržaja kulture i medija prema Kurikulumu za nastavni predmet Hrvatski jezik za osnovne škole i gimnazije u Republici Hrvatskoj iz 2019. godine. Upozorava se na negativan utjecaj tehnologije i medija, prvenstveno interneta i društvenih mreža na razvoj kognitivnih procesa kod djece, ali se navode i primjeri dobre prakse.
\end{abstract}

Ključne riječi: mediji, kurikulum, kultura i mediji, internet, društvene mreže, multimedija, Facebook

\section{Što smatramo pod pojmom mediji?}

Mediji su prisutni u svim područjima života. Rabe ih osobe svih životnih dobi pa se povećanom tehnologizacijom i modernizacijom sve više javlja potreba njihova korištenja u nastavi. S druge strane, sve veća upotreba mobilnih uređaja i interneta kod djece dovodi do različitih oblika ponašanja koji se reflektiraju u njihovim kognitivnim procesima i ponašanju.

Za početak, potrebno je definirati što se u ovom radu podrazumijeva pod pojmom medija. U didaktičkom i komunikološkom smislu, medij označuje svaki predmet, katkad i osobu, koji može uskladištiti (spremiti), prenositi i prezentirati podatke i informacije, ali i alate kojima se obavljaju određeni radni zadaci (DVD, USB, hard disk). ${ }^{1}$ Dolazi od latinske riječi medium koja označava sredinu i način na koji se nešto iskazuje, sredstvo komunikacije. ${ }^{2} \mathrm{U}$ komunikacijskim znanostima takvima se smatraju tiskovine i elektronička sredstva; u novije doba internet, komunikacijski sateliti, film, CD te se o njima govori kao o masovnim medijima. ${ }^{3}$

1 Milan Matijević i Tomislav Topolovčan, Multimedijska didaktika, Zagreb 2017., 43.

2 Vladimir Anić, Rječnik stranih riječi, Zagreb 2000., 523.

3 http://www.enciklopedija.hr/Natuknica.aspx?ID=39755 (31. 8. 2018.) 
Masovni mediji razlikuju se prema tipu: knjiga, tisak (novine), film, televizija, radio, nosači zvuka i slike (video, CD, DVD); razini i dosegu: lokalni, nacionalni, međunarodni te obliku vlasništva: privatni, javni, državni. Masovni mediji mogu reproducirati poruke u neograničenu broju, namijenjeni su prodaji i dostupni svim članovima društva. Publiku masovnih medija čine pojedinci koji primaju i raznoliko dekodiraju poruke i sadržaje medija. Zbog povećanoga broja medijskih vrsta i kanala, publika je sve raznolikija. Tradicionalni masovni mediji sve se više povezuju s računalnom tehnologijom pa nastaju novi interaktivni mediji, kao što je internet - koji više nije tipičan masovni medij zbog čega se termin masovni mediji sve češće zamjenjuje terminom komunikacijski mediji. Masovni mediji plod su tehnoloških inovacija (tiskarski stroj, kamera, prijenos radiovalova, računala, digitalizacija). ${ }^{4}$

Medije koji se upotrebljavaju u obrazovnom sustavu možemo podijeliti na tiskane, netiskane i elektroničke medije. Tiskani mediji uključuju knjige, časopise, novine i radne knjige. Netiskani mediji uključuju projekcijske i neprojekcijske medije. Projekcijski mediji su mediji koji koriste svjetlost za projekcije. To su filmovi, projekcije, prezentacije (Power Point, Prezi). Neprojekcijski mediji su oni koji ne koriste svjetlost. To su ploče, modeli, grafikoni. Elektronički mediji u edukaciji dijele se na auditivne, vizualne i audiovizualne medije. Auditivni mediji su audiokasete, audiosnimke i radioprijemnici. Vizualni mediji su računala za nastavu, kalkulatori, pametne ploče. Mogu se podijeliti i na klasične: tisak, radio, film i televizija, te suvremene: internet, multimedija, računalne igre, digitalna fotografija. ${ }^{5}$

\section{Organizacija i nastavni program odgoja za medije u hrvatskom osnovnoškolskom obrazovanju}

Hrvatski obrazovni sustav sastoji se od ranog i predškolskog odgoja i obrazovanja, osnovnog, srednjeg i visokog obrazovanja. Osnovnoškolsko i srednjoškolsko obrazovanje definirano je Zakonom o odgoju i obrazovanju u osnovnoj i srednjoj školi iz 2008. godine koji je izmijenjen i nadopunjen 2009., 2010., 2011., 2012. te je najnovija izmjena na snagu stupila u kolovozu 2019. godine.

\footnotetext{
$4 \quad$ Hrvatska enciklopedija; http://www.enciklopedija.hr/natuknica.aspx?ID=39312 (31. 8. 2018.)

5 Siniša Medved, „Pretpostavke za razvoj primarnog medijskog obrazovanja u Hrvatskoj“, Završni rad, Varaždin 2015., 4.
} 
Na razini Republike Hrvatske Ministarstvo znanosti, obrazovanja i sporta donosi Nacionalni okvirni kurikulum. Taj dokument predstavlja osnovne sastavnice predškolskoga, općega obveznoga i srednjoškolskoga odgoja i obrazovanja, uključujući odgoj i obrazovanje za djecu s posebnim odgojno-obrazovnim potrebama. Osnova je za razradu predmetne strukture područja, određivanje predmeta i modula jezgrovnoga kurikuluma, izbornih predmeta i modula, opterećenja učenika. ${ }^{6}$ Iz Nacionalnoga kurikuluma proizlazi Nastavni plan i program za osnovnu školu te Nastavni program za gimnazije, Nastavni program za prirodoslovne gimnazije, Nastavni program za strukovne škole i Nastavni program za umjetničke škole u kojima su definirane sve teme koje trebaju biti obrađene tijekom školske godine po predmetima, predmetnim područjima i razredima. Prema njemu nastavnici izrađuju godišnje planove i programe (po mjesecima) te izvedbene planove (po satima). Sve aktivnosti koje nisu definirane godišnjim planom i programom, a odvijaju se tijekom školske godine u određenoj školi, poput izvannastavne i izvanučioničke nastave, sačinjavaju školski kurikulum. Međutim, od 2019. godine nastavni planovi i programi stupili su izvan zakona, a uvedeni su novi, predmetni kurikulumi prema kojima se podučava u petim razredima osnovnih škola i prvim razredima gimnazija šk. god. 2019./2020. nastava Hrvatskoga jezika, u sedmim razredima nastava Kemije, Biologije i Fizike, a u prvim razredima cjelokupna nastava. Reforma će se postupno provoditi i u ostalim razredima u nadolazećim godinama.

Odgoj za medije u hrvatskom obrazovnom sustavu uči se u sklopu predmeta Hrvatski jezik. Do šk. god. 2019./2020. podučavao se kao predmetno područje medijska kultura i to samo u osnovnoj školi. Kurikulumom nastavnoga predmeta Hrvatski jezik za osnovne škole $i$ gimnazije iz 2019. godine, dosadašnjih pet predmetnih područja (jezik, književnost, jezično izražavanje, lektira i medijska kultura) u nastavi Hrvatskoga jezika promijenjeno je u tri: književnost i stvaralaštvo, kultura i mediji te hrvatski jezik i komunikacija (u prvim i petim razredima). Dakle, ono što se podučavalo u sklopu medijske kulture, sada se podučava u sklopu kulture i medija. Osim osnovnih škola te kao izborni sadržaj u srednjim školama, prema podacima dostupnima od Ministarstva znanosti i obrazovanja, u sedamnaest srednjih škola

$6 \quad$ Nacionalni okvirni kurikulum za predškolski odgoj te opće obvezno i srednjoškolsko obrazovanje (2010.), 11. 
u Republici Hrvatskoj izvode se predmeti koji u nazivu sadrže Medij ili Medijska, poput: Elektronički mediji, Medijska fotografija, Medijska kultura, Medijska prezentacija, Medijski projekti, Multimedijske tehnologije, Napredne medijske tehnologije i Vizualna i medijska kultura. Međutim, kod velikog dijela riječ je o školama u kojima postoje programi za zanimanja usko vezana za medije. ${ }^{7}$

Predmetni kurikulumi pisani su na način da su usmjereni na ishode. Ishodi znanja (learning outcomes) opisuju kompetencije koje se prikazuju kroz znanja, vještine te pripadajuću samostalnost i odgovornosti koje učenik može pokazati nakon završetka procesa učenja (prije to ni ne može). Svaki opisani ishod na mikrorazini ima tri komponente: očekivanu vještinu opisanu aktivnim glagolom (prema revidiranoj Bloomovoj taksonomiji), uvjete i minimalni kriterij prolaznosti. ${ }^{8}$ Oni su jasni i mjerljivi, a proizlaze iz područja znanja: kognitivnoga, društveno-afektivnoga i psihomotoričkoga te iz razina (dimenzija) znanja: činjeničnoga, konceptualnoga, proceduralnoga i metakognitivnoga znanja.

Ovdje ćemo navesti dosadašnji program odgoja o medijima prema Nastavnom planu i programu za osnovne škole te ga usporediti s novim, Kurikulumom nastavnoga predmeta Hrvatski jezik za osnovne škole i gimnazije.

Prema Nastavnom planu i programu za osnovne škole iz 2006. godine, zadaće su medijske kulture osposobljavanje za komunikaciju s medijima: kazalištem, filmom, radijem, tiskom, stripom, računalom; primanje (recepcija) kazališne predstave, filma, radijske i televizijske emisije; osposobljavanje za vrednovanje radijskih i televizijskih emisija te filmskih ostvarenja. ${ }^{9}$ O medijima se može učiti unutar dramske ili filmske grupe, međutim, ona proizlazi iz same zainteresiranosti nastavnika i učenika te nije dio obveznoga obrazovnog programa. Medijska kultura u gimnazijama dio je izborne nastave Hrvatskog jezika, ali se zbog velikog opsega obveznoga nastavnog gradiva rijetko kada realizira. Prema Kurikulumu nastavnog predmeta $\mathrm{Hr}$ vatski jezik za osnovne škole i gimnazije iz 2019. godine, predmetno područje kultura i mediji temelji se na razumijevanju teksta u različitim društvenim, kulturnim i međukulturnim kontekstima. Predmetnim se područjem potiče razvoj znanja o sebi i drugima, uvažavanje različitih uvjerenja i vrijednosti te se omogućuje djelovanje u društvenoj zajednici. ${ }^{10}$

7 Medved, „Pretpostavke za razvoj“, 13.

8 Marijana Marinović, Nastava povijesti usmjerena prema ishodima učenja. Metodički priručnik za nastavnike povijesti, Zagreb, 2014., 19.

9 Nastavni plan i program za osnovnu školu (2006), 25., Medved, „Pretpostavke za razvoj“, 15.

10 Kurikulum nastavnog predmeta Hrvatski jezik za osnovne škole i gimnazije, 4. 
Predmetno područje obuhvaća: kritički odnos prema medijskim porukama, razumijevanje utjecaja medija i njihovih poruka na društvo i pojedinca; stvaranje medijskih poruka i njihovo odgovorno odašiljanje; razumijevanje kulture s gledišta svakodnevnoga života, s društvenoga gledišta, kulture u odnosu na popularnu kulturu i kulture u odnosu prema književnosti i ostalim umjetnostima te utjecaj kulture na oblikovanje vlastitoga kulturnog identiteta te poticanje svjesnosti o jedinstvenosti i vrijednosti različitih mišljenja, stavova i ideja, društava i kultura radi uspješne komunikacije te razumijevanja drugih i drukčijih. ${ }^{11}$

Prema Nastavnom planu i programu za osnovne škole iz 2006. godine, naglasak nastave medijske kulture je na filmskom obrazovanju, a navest ćemo koje se teme obrađuju u određenom razredu.

U prvome razredu iz medijske kulture nastavnici moraju obraditi teme: animirani film, lutkarsku predstavu i knjižnicu. Učenici moraju biti upoznati s lutkarskim i crtanim filmom te ih naučiti razlikovati. Moraju doživjeti lutkarsku predstavu; navesti glavne likove, oživiti scensku lutku i izvesti kraći ulomak igrokaza, te moraju upoznati školsku i mjesnu knjižnicu, naučiti posuđivati, čuvati i vraćati knjige i razlikovati knjižnicu od knjižare. ${ }^{12}$

U drugome razredu zadane su teme: filmska priča, kazalište, televizija i dječji časopisi. Učenici u drugom razredu percipiraju primjerene dječje filmove, moraju zamijetiti i odrediti slijed događaja u filmu, ispričati filmsku priču kratkoga crtanoga filma i razlikovati glavne i sporedne likove u filmu. Iz teme kazališta moraju naučiti percipirati primjerene kazališne predstave, razlikovati kazališnu predstavu od filma, razlikovati pozornicu od gledališta. Što se tiče televizije moraju znati definirati pojmove: televizija, televizijski program i televizijska emisija te moraju izdvojiti najdražu emisiju iz televizijskog programa i razgovarati o njoj. Za temu dječji časopisi moraju upoznavati neke dječje časopise i stripove u njima, čitati ih i razlikovati od ostaloga tiska. ${ }^{13}$

U trećemu razredu medijska kultura obuhvaća: dječji film, radijsku emisiju i knjižnicu - korištenje enciklopedije. Učenici moraju percipirati primjerene dječje filmove, razlikovati igrani film za djecu od animiranoga filma i ispričati filmsku priču, percipirati radijsku emisiju za djecu, raspravljati o njoj i zamijetiti zvučna izražajna sredstva te

11 Kurikulum, 4.

12 Nastavni plan i program, 27-28.

13 Isto, 29-30. 
moraju znati pronaći traženu obavijest u dječjoj enciklopediji služeći se kazalom i abecednim redom. ${ }^{14}$

U četvrtome razredu zadane su četiri teme: dokumentarni film, usporedba filma s književnim djelom, računalo i knjižnica - služenje rječnikom i školskim pravopisom. Učenici moraju percipirati primjerene dokumentarne filmove (ekološki sadržaj, zavičajna tematika), zamijetiti osnovna obilježja dokumentarnoga filma, percipirati nekoliko dječjih filmova nastalih prema književnome predlošku, iskazivati vlastiti doživljaj književnoga djela i filma, zamijetiti sličnosti i razlike između filma i književnoga djela prema kojemu je snimljen, razlikovati obavijesne i zabavne mogućnosti računala te pronaći traženu obavijest u školskome rječniku ili pravopisu služeći se kazalom i abecednim redom. ${ }^{15}$

U petome razredu zadano je pet tema mediji, filmski rodovi, animirani film, tisak i kazalište. Učenici moraju osvijestiti postojanje različitih vrsta medija, navesti primjer za priopćajni proces u jednome od medija, prepoznati i razlikovati filmske rodove (dokumentarni film, animirani film, igrani film), prepoznati osnovna obilježja animiranoga filma, razlikovati crtani film od lutkarskoga filma, prepoznati i razlikovati vrste tiska i što se tiče teme kazališta uočiti suprotstavljene likove, prepoznati kazališna izražajna sredstva u predstavi: scenografiju, kostimografiju, rasvjetu. ${ }^{16}$

U šestome razredu zadane su tri teme iz nastavnog područja medijska kultura: filmska izražajna sredstva, mreža (internet) i strip. Učenici u šestom razredu moraju naučiti prepoznati izražajna sredstva u filmu, razlikovati vrste kadrova, planova i kuta snimanja, pronaći nekoliko mrežnih stranica o temama iz hrvatskoga jezika i književnosti i prepoznati izražajna sredstva stripa, uočiti sličnost i razliku između filmskoga kadra i kvadrata stripa (plan i kut gledanja). ${ }^{17}$

U sedmome razredu zadane su četiri teme: igrani film, televizijska emisija, radio i knjižnica. Učenici moraju prepoznati i objasniti obilježja igranoga filma i filmske priče, uočiti ideju te odnose među likovima i izražajna sredstva, razlikovati vrste igranoga filma, usporediti film i književno djelo, razlikovati vrste televizijskih emisija s obzirom na njihovu namjenu, prepoznati radijska izražajna sredstva, razlikovati

14 Nastavni plan i program, 32.

15 Isto, 34.

16 Isto, 37.

17 Isto, 41. 
vrste radijskih emisija, osvijestiti obavijesnu, obrazovnu i zabavnu ulogu radija i samostalno se služiti referentnom zbirkom: rječnikom, enciklopedijom i pravopisom. ${ }^{18}$

U osmome razredu zadane su četiri teme iz nastavnog područja medijska kultura: scenarij i knjiga snimanja, dokumentarni film, Zagrebačka škola crtanog filma i tema „U potrazi za knjigom“. Učenici moraju razlikovati scenarij i knjigu snimanja, uočiti ulogu redatelja, razlikovati dokumentarni film od ostalih filmskih rodova, razlikovati vrste dokumentarnih filmova, uočiti filmska izražajna sredstva u dokumentarnome filmu, uočiti obilježja Zagrebačke škole crtanoga filma, navesti imena najznačajnijih autora i pod temom „U potrazi za knjigom" samostalno ili uz pomoć knjižničara pronaći podatke o određenome knjižnome naslovu kataloškim i računalnim pretraživanjem. ${ }^{19}$

Prema Kurikulumu nastavnoga predmeta Hrvatski jezik iz 2019. godine, naglasak više nije na filmskoj umjetnosti, već na odgoju za medije, upoznavanju s različitim vrstama medija te stvaranju kritičkoga mišljenja o njima. U prvome razredu učenik bi trebao moći izdvojiti jedan ili više podataka iz teksta prema unaprijed zadanim pitanjima, služiti se dječjim rječnicima, pronaći natuknicu prema abecednome redu, crtežom i riječima izraziti o čemu tekst govori, izdvojiti primjerene medijske sadržaje i razgovarati o njima (kao što su: animirani filmovi, televizijske i radijske emisije za djecu obrazovnoga i dječjeg programa, kazališne predstave, slikovnice i knjige za djecu), slušati čitanje ili samostalno čitati kraće tekstove u književnim i zabavnopoučnim časopisima za djecu, prepoznati obrazovne digitalne medije primjerene dobi i služiti se njima, posjećivati kulturne događaje primjerene dobi, razgovarati s ostalim učenicima nakon kulturnoga događaja, izraziti svoj doživljaj kulturnoga događaja crtežom, slikom, govorom, pokretom, pjevanjem. ${ }^{20}$

U drugome razredu, kao i u prvome, učenik treba prepoznati važne podatke u kratkome tekstu, izdvojiti iz teksta jedan ili više podataka prema zadanim uputama. Osim toga, treba moći prepričati sadržaj teksta, izdvojiti primjerene medijske sadržaje i razgovarati o njima izražavajući vlastito mišljenje, gledati i slušati animirane filmove, dokumentarne i igrane filmove za djecu - pratiti (gledati, slušati, doživljavati) televizijske i radijske emisije za djecu obrazovnoga i dječjega

18 Nastavni plan i program, 45.

19 Nastavni plan i program, 49., Medved, „Pretpostavke za razvoj“, 15-17.

20 Kurikulum, 7-8. 
programa. Treba samostalno čitati kraće tekstove u književnim i zabavno-poučnim časopisima za djecu, prepoznati obrazovne i interaktivne digitalne medije primjerene dobi i služiti se njima, posjećivati kulturne događaje te razgovarati s ostalim učenicima nakon njih, izdvojiti što mu se sviđa ili ne u vezi s istima te iskazati svoj doživljaj. ${ }^{21}$

U trećemu razredu učenik bi trebao moći prepoznati različite izvore informacija: digitalne udžbenike, tekstove u zabavno-obrazovnim časopisima i knjigama za djecu te na obrazovnim mrežnim stranicama, pronalaziti i kombinirati podatke iz različitih izvora primjerenih dobi, izdvojiti važne podatke iz teksta i razvrstati ih prema uputi, te prenijeti tekst u druge oblike ili medije, razlikovati knjige, udžbenike, časopise, plakate, strip, brošure, reklamne letke, samostalno i redovito čitati tekstove u književnim i zabavno-obrazovnim časopisima za djecu i iskazati mišljenje o njima, čitati stripove i razlikovati ih od ostalih tiskanih medijskih tekstova, stvoriti kroz igru vlastite uratke potaknute određenim medijskim sadržajem te, jednako kao i u dosadašnjim razredima, iskazati svoje mišljenje o kulturnim događajima kojima prisustvuje. ${ }^{22}$

U četvrtome razredu treba prepoznati moguće izvore podataka i informacija kao što su stručnjaci ili drugi pojedinci, školske ili narodne/ gradske knjižnice te internet; doći do podataka kombinirajući različite izvore; prepoznati, preuzeti, pregledavati i objašnjavati materijale sa školske mrežne stranice; upotrebljavati podatke u različite svrhe: proširiti sadržaje učenja, pripremati se za pisanje i govorenje, razlikovati televiziju, radio te internet; gledati emisije za djecu i razgovarati o njima, objasniti razliku između novinskih priloga na televiziji i radiju (primjerice, intervju), pristupiti društvenim mrežama uz vođenje i usmjeravanje te pretražiti mrežne portale za djecu, gledati animirane, dokumentarne i igrane filmove i filmove dječjega filmskog stvaralaštva tematski i sadržajno primjerene recepcijskim i spoznajnim mogućnostima; zamjećivati sličnosti i razlike između književnoga djela, kazališne predstave ili filma nastalih prema književnome djelu; ponovno posjećivati i sudjelovati u kulturnim događajima (likovnim, glazbenim, znanstveno-popularnim). ${ }^{23}$

$\mathrm{U}$ petome razredu valja razlikovati tiskane medijske tekstove prema učestalosti izlaženja: dnevne novine, tjedne, mjesečne i godišnje

21 Nastavni plan i program, 10-11.

22 Kurikulum, 13-14.

23 Isto, 16. 
časopise, uočavati uporabu i organizaciju pojedinih sadržajnih i grafičkih elemenata u različitim tiskanim medijskim tekstovima radi prenošenja poruke, prepoznati kako se grafičkim elementima (naslov, nadnaslov, podnaslov, fotografija/ilustracija, okvir) oblikuje značenje medijske poruke i stvara željeni učinak na primatelja; izdvajati sadržaje koji promiču pozitivne vrijednosti i potiču pozitivne komunikacijske obrasce; uočavati vezu teksta i svijeta koji ga okružuje; opisati značenje popularnokulturnih tekstova i povezati ih sa svakodnevnim životom; uočavati priču kao temelj popularnokulturnih tekstova; upoznati pojam popularne kulture te povezati popularnokulturne tekstove sa svakodnevnim životom. ${ }^{24}$

U šestome razredu učenik treba uočavati podjelu na komercijalne i nekomercijalne medije, uočavati predstavljanje istih medijskih sadržaja u različitim medijima, objašnjavati reakcije različitih primatelja na isti medijski tekst, pretpostaviti o ciljanoj publici na temelju pročitanoga teksta/pogledane predstave/filma/serije, opisati kako se različitim postupcima, tehnikama te vizualnim i zvučnim znakovima oblikuje značenje medijske poruke i stvara željeni učinak na publiku; objasniti vezu teksta i svijeta koji ga okružuje, objasniti značenje popularnokulturnih tekstova i povezati ih s vlastitim interesima, željama i iskustvom, uočavati priču i likove kao temelje popularnokulturnih tekstova, tj. kao objekte znatiželje, sviđanja/nesviđanja, izdvajati dijelove popularnokulturnih tekstova koji predstavljaju razlike i različita uvjerenja, prepoznati popularnokulturne tekstove kao dio trenutačne društvene stvarnosti, usporediti vlastita i tuđa mišljenja o popularnokulturnim tekstovima u skladu s dosadašnjim iskustvom; objasniti pojam popularne kulture na poznatim primjerima popularnokulturnih tekstova. ${ }^{25} \mathrm{U}$ sedmome razredu treba moći objasniti svoju reakciju na medijski tekst, usporediti reakcije različitih primatelja na isti medijski tekst, suprotstaviti se stereotipima, predrasudama, pristranosti, prikrivenoj i otvorenoj diskriminaciji i govoru mržnje, opisati usklađenost i svrhovitost elemenata medijske poruke/medijskih tekstova/ sadržaja u različitim časopisima; tumačiti vezu teksta i svijeta koji ga okružuje; opisati ulogu popularne glazbe u izražavanju temeljnih pitanja mladenačkoga identiteta, obrazložiti značenje popularnokulturnih tekstova i povezati ih s društvenim i ekonomskim okružjem (npr. bi-

24 Kurikulum, 19-20.

25 Isto, 22-23. 
ografije poznatih koje prikazuju društvenu i ekonomsku raslojenost); povezati popularnokulturne tekstove s društvenim i ekonomskim okružjem; tumačiti priču i likove kao temelje popularnih tekstova, tj. kao objekte divljenja ili osude; izdvojiti dijelove teksta koji predstavljaju predrasude i stereotipe; objasniti postojanje različitih, njemu poznatih supkultura; usporediti popularnu kulturu s tzv. visokom umjetnošću na poznatim primjerima iz književnosti ili drugih umjetnosti. ${ }^{26}$

U osmome razredu treba uočavati sliku stvarnosti koju predstavljaju mediji radi komercijalizacije i usporediti je s vlastitom slikom stvarnosti, objasniti utjecaj medijskih poruka na oblikovanje vlastitih stavova, samostalno izabrati i preraditi medijske poruke za stvaranje pretpostavki i donošenje odluka, uočiti internet kao platformu: internet kao medij svih medija; uočiti sastavne elemente hipermedija: međusobno povezani tekst, sliku, video i zvuk; služiti se poveznicama koje proširuju sadržaj teksta; obrazložiti vezu teksta i svijeta koji ga okružuje; prosuditi značenje popularnokulturnih tekstova povezujući ih s društvenim, ekonomskim i kulturnim okružjem; tumačiti priču i likove kao temelje popularnokulturnih tekstova, tj. kao objekte identfikacije; objasniti postojanje različitih, njemu poznatih supkultura (gejmeri, šminkeri, emoi, hipsteri...) te usporediti popularnu kulturu s tzv. visokom kulturom na poznatim primjerima iz književnosti ili drugih umjetnosti. ${ }^{27}$

Unatoč tomu što sadržaj medijske kulture, odnosno, po novome, kulture i medija, bogat, broj nastavnih sati koji otpada na njezino izvođenje je neznatan. Od prvoga do šestoga razreda godišnji broj sati Hrvatskog jezika iznosi 175, a u sedmome i osmome razredu 140 sati. Od toga svega desetak sati godišnje otpada na medijsku kulturu što je iznimno malo u odnosu na to koliko smo okruženi medijima i koliko bi djecu trebalo usmjeriti na pravilnu i svrhovitu upotrebu istih. Prema novom kurikulumu, preporučen broj sati iz predmetnoga područja kultura i mediji je 10\% ukupnih sati Hrvatskoga jezika, što iznosi otprilike 17-18 od prvoga do šestoga te 14 u sedmom i osmom razredu, uz moguće odstupanje od 10\% svakoga predmetnoga područja (kultura i mediji, književnost i stvaralaštvo, hrvatski jezik i komunikacija).

26 Kurikulum, 26-27.

27 Isto, 30. 


\section{Multimedijska nastava}

Trenutačno su u didaktici dominantne konstruktivističke teorije učenja koje stavljaju naglasak na aktivnost i suradnju učenika u okolini učenja. Neizostavni element suvremene okoline učenja svakako su digitalni mediji. Oni omogućuju učenje istraživanjem, rješavanjem problema, projektno i suradničko učenje, učenje igrom, učenje usmjereno prema djelovanju te situacijsko učenje. Mediji su važni jer posreduju iskustva učenja kojima se postižu željeni ishodi na kojim se temelje kurikulumi. ${ }^{28}$ Multimedijalnost podrazumijeva istodobno djelovanje dvaju ili više singularnih medija koji se međusobno upotpunjuju i obogaćuju u djelovanju, npr. filmski zapis sa zvukom i govornim objašnjenjem. ${ }^{29}$

Nastavni mediji prema osjetilima koja su primarna za njihovo korištenje možemo podijeliti na: auditivne (svi uređaji koji omogućuju snimanje i reprodukciju zvuka: MP3 elektronički uređaji, mobilni telefoni, ali i sami zvučni zapisi: zvučni zapisi s internetskih portala, radijske emisije, zvučni zapisi koje snima učenik za učenje te snimljeni zvučni zapis za učenje stranoga jezika), vizualne (svi koji prikazuju sliku: tiskani i digitalni udžbenici, simulacije, Power Point) i audiovizualne medije (filmovi videoisječak, znanstveno-popularno predavanje, multimedija za samostalno učenje, videoigre te računalne simulacije), no postoje i novi koji se ne mogu svrstati u ove tri kategorije te ih nazivamo digitalnim medijima, a uz njih se javljaju i nazivi: hipermedij, hipertekst i multimedija. Hipermedij je zajednički naziv za interaktivne programe u kojima su pohranjene informacije u više medija. Informacije se mogu upotrebljavati i prezentirati na više različitih načina, pretražuju se na interaktivan način, aktiviranjem poveznica tj. vrućih točaka. U osnovi hipermedija je hipertekst koji je obogaćen raznim grafičkim, filmskim i animacijskim materijalima. Multimedija je zajednički naziv za multimedijski softver koji se nalazi na kompaktnom disku (CD-u), DVD-u, USB-u ili je dostupan na internetu. Osim toga, postoji i pojam virtualna stvarnost koja se stvara pomoću simulacije. Ulaženjem korisnika u računalno generiranu i simuliranu okolinu stječe se dojam stvarnosti. ${ }^{30}$

Multimedijska nastava označuje upotrebu dvaju ili više medija koji

29 Isto, 43.

30 Isto, 46-48. 
se nadopunjuju i obogaćuju u odgovarajućim strategijama učenja s obzirom na željene ishode. Primjerice, upotreba slike, teksta, vizualnih, auditivnih i audiovizualnih materijala te digitalnih medija kao što su računalo, internet ili mobilni telefon. To je ukomponirano u učenje i poučavanje licem u lice te u komunikaciju pomoću digitalnih medija. ${ }^{31}$ Okolinu za multimedijsku nastavu potrebno je opremiti odgovarajućim predmetima i digitalnim medijima koji potiču učenika na tjelesne i kognitivne aktivnosti, pri čemu je bitna i odgovarajuća interakcija između učitelja i učenika. ${ }^{32}$ Suvremeni digitalni mediji omogućuju višestruku digitalnu prezentaciju, prenošenje i pohranjivanje nastavnih sadržaja, digitalnu potporu u obavljanju raznih radnji te digitalno posredovanu komunikaciju. Sadržaji koji su prije bili u tekstualnim i tiskanim oblicima, poput knjiga i udžbenika, sada se prezentiraju, prenose i pohranjuju u digitalnom obliku. Svi oni potpomognuti su pristupom internetu. Digitalna potpora podrazumijeva obavljanje radnji i zadataka pomoću digitalnih medija i tehnologija te je zamijenila nekadašnju ručnu obradu. Primjerice, tehničko crtanje koje se prije obavljalo olovkom i ravnalima te se primjenjuje u arhitekturi ili građevini zamijenjeno je programima za crtanje i projektiranje kao što su AutoCAD. Isto tako, ručnu obradu drva i metala zamijenili su CNC strojevi. Čak se i klasični udžbenici zamjenjuju e-udžbenicima na kojima su u digitalnom obliku pohranjeni svi podaci kao i na tiskanom te mu je moguće pristupiti pomoću računala, prijenosnih računala ili tableta. Cilj mu je rasteretiti učeničke torbe. Digitalna komunikacija podrazumijeva apersonalnu komunikaciju SMS porukama, elektroničkom poštom, videokonferencijskim programima, društvenim mrežama kao što su Facebook ili Skype, a digitalni mediji omogućuju i različite vrste rada kao što su: frontalni, grupni, tandemski i individualni rad te različite vrste učenja: situacijsko, učenje istraživanjem, učenje rješavanjem problema, suradničko učenje, učenje igrom, projektno učenje te učenje usmjereno prema djelovanju. Multimedijska nastava usmjerena je prema učeniku te je njezin naglasak na učenju, a ne na poučavanju. Ukratko, učitelj samo usmjerava učenika u procesu spoznaje, a učenik bi trebao biti sposoban vrednovati koliko dobro poznaje gradivo (samoevaluacija), naučiti kako učiti te sam upravljati svojim učenjem (samoregulacija), ${ }^{33}$ što po završetku škole dovodi do odrasle

31 Matijević i Topolovčan, Multimedijska didaktika, 57.

32 Isto, 58.

33 Isto, 59-60. 
osobe koja je spremna na to da će morati nastaviti učiti cijeloga života, no ne u školi, već u različitim područjima života, ponajprije u svojoj struci ako želi napredovati u poslu, biti bolji zaposlenik te ići „u korak s vremenom“. Učitelj je taj koji ga prati na njegovu putu, vrednuje njegovo znanje i, u konačnici, donosi ocjenu. Vrednuje se cijeli proces, a ne samo rezultat, a to je ono što se kurikularnom reformom u Hrvatskoj htjelo i postići.

Današnji učitelji moraju se suočavati s mnogobrojnim izazovima. Osim toga da trebaju „ići“ u korak s vremenom, veliki problem je nedostatak koncentracije kod djece, pogotovo zbog raznih digitalnih medija kojima su izloženi i koji im najviše i odvlače pozornost i na koje gube poprilično vremena, i to ne samo djeca, već i odrasle osobe. Današnji učenici osnovnih i srednjih škola teško prihvaćaju nastavne scenarije prema kojima moraju sjediti, slušati i gledati što i kako rade nastavnici. Nezamislivo im je da dva sata čitaju knjigu, neovisno o tome koliko je zanimljiva. Teško se odlučuju u ruke uzeti knjigu u opsegu od 300 do 400 stranica. ${ }^{34}$ Radije obavljaju više radnji, npr. crtaju slušajući glazbu i prateći prikaze na televiziji, ili usto imaju i uključen mobilni telefon te povremeno zaprimaju odgovore na poruke koje su poslali ili šalju nove. ${ }^{35}$ Prvenstveno su vizualni tipovi i teško razumijevaju apstraktne pojmove i preneseno značenje poput metafore, alegorije, ironije i sarkazma, što je rezultat nedovoljnoga čitanja, slaboga rječnika te slabo razvijene mašte. U konačnici, slabije razumiju i humor temeljen na ironiji ili sarkazmu. Ukratko, i djeca i odrasli moraju naučiti upravljati digitalnim medijima kako ne bi postali robovi te tehnologije. Pod time se smatra da znaju programirati i instalirati nužne aplikacije na svojim uređajima koji im služe kako bi mogli pretraživati podatke i programe, a ne da bi cjelokupno vrijeme provodili služeći se tim uređajima. Trebaju naučiti planirati svoje vrijeme tako da za sve imaju dovoljno vremena, a da ničega ne bude previše. ${ }^{36}$

Zainteresiranost učenika za upotrebu interneta te društvenih mreža, učitelji bi mogli iskoristiti kao alat pomoću kojega će učenicima približiti ponekad njima dosadno ili nezanimljivo gradivo i pretvoriti ih $\mathrm{u}$ aktivne subjekte. U sljedećem poglavlju navest će se nekoliko primjera kako upotrebljavati najpopularniji medij današnjice - internet.

34 Matijević i Topolovčan, Multimedijska didaktika, 65., 68

35 Isto.

36 Isto, 72. 


\section{Svrhovita upotreba interneta u nastavi Povijesti: primjeri dobre prakse}

Internet kao najčešće upotrebljavani medij današnjice pruža brojne mogućnosti u podučavanju nastave Povijesti. Povijest nam je postala dostupnija i pristupačnija te se na brojnim internetskim stranicama nalaze cjeloviti ili fragmentirani povijesni izvori, posebice iz najnovije prošlosti, 20. pa i 21. stoljeća. Unatoč tome što brojne znanstvene institucije na svojim mrežnim stranicama objavljuju korisne povijesne podatke, internet obiluje i brojnim stranicama senzacionalističkih naslova, popularne povijesti, pristranih izvora i često neprovjerenih informacija. Stoga, ako se profesor odluči upotrijebiti internet kao alat za podučavanje i učenje u multimedijskome okruženju, jako je bitno da svoga učenika upozori na potencijalne poteškoće u pretraživanju interneta te da ga uputi u temu i zadatak tako da on ne samo da pretražuje, već i da istražuje, da stvori kriterije kako procijeniti koje se informacije s internetskih stranica mogu upotrijebiti u nastavi, a s kojih stranica dolaze neprovjerene informacije. ${ }^{37}$ Nastavnik je ključan $u$ usmjeravanju učenika ili na pouzdane stranice kao što su online enciklopedije ili rječnici, mrežne stranice muzeja, arhiva ili knjižnica te ključne riječi pomoću kojih će pretraživati. Jednako kao i u izvorima u udžbenicima, treba obratiti pozornost na pitanja tko je autor izvora, kada je nastao, kome je upućen, zašto se dokument sačuvao, mogu li se informacije iz toga dokumenta provjeriti i potvrditi i drugim izvorima itd. Jedna od korisnih metoda jest i usporedba više članaka s različitih internetskih stranica koji se bave istom temom tako da se tablično prikaže različitost ili istovjetnost podataka s različitih stranica. Učenici moraju znati što traže - to je jako važno pri smišljanju i upisivanju ključnih riječi u tražilicu koje će dovesti do odgovora tj. rješenja postavljenoga zadatka ili pronalaska stranice. Potrebno je skrenuti pozornost na sužavanje potrage ako upisane riječi daju preopćenite podatke te ih uputiti kako da označe tj. sačuvaju stranice koje su pronašli kao korisne. ${ }^{38}$

Ovdje možemo navesti i primjer upotrebe društvenih mreža u nastavi povijesti, primjerice Facebooka. Primjer iz vlastite prakse u članku „Facebook - nova obrazovna platforma u nastavi Povijesti“ donijeli su Andrea Vučetić i Sergej Filipović. Svojim istraživanjem htjeli su

37 Robert Stradling, Nastava europske povijesti 20. stoljeća, Zagreb 2005., 169-190.

38 Isto, 169-190. 
riješiti četiri zadatka: provjeriti zainteresiranost učenika za učenje Povijesti preko Facebooka, usporediti prosječnu ocjenu razrednih odjela u prijašnjem školskom testu s ocjenom iz nastavnoga sadržaja obuhvaćenoga istraživanjem, po istom principu usporediti ocjene učenika pojedinačno te pristupiti svakom učeniku na individualan način. Nakon zadobivenih suglasnosti ravnatelja i stručne službe škole te roditelja, svoj su eksperiment proveli u trima odjelima šestih razreda (dvanaestogodišnjaci) Osnovne škole Julija Kempfa u Požegi. Dobili su pristanak 71 roditelja (od ukupnoga broja 74), a testiranje je provedeno na 69 učenika jer su dvojica od onih čiji su roditelji pristali, bili odsutni. Tijekom tri tjedna preko Facebooka i to preko Power Point prezentacija za pet nastavnih jedinica, obrađena je nastavna cjelina „Hrvatska u doba Arpadovića i Anžuvinaca“ te je svaka učitana u zajedničku grupu na Facebooku (u kojoj su bili svi testirani učenici). Nakon svake nastavne jedinice, održan je kviz od dvadeset pitanja u kojem su testirali svoje znanje (što bi prema novom Pravilniku o načinima, postupcima i elementima vrednovanja u osnovnoj i srednjoj školi odgovaralo pojmu vrednovanje kao učenje koje uključuje učeničku samoprocjenu znanja). Svakom učeniku ponaosob vraćeni su odgovori s točnim odgovorima te objašnjenjima u čemu su pogriješili. ${ }^{39}$ Nakon provedenoga testa, učenicima je ponuđen anketni listić u kojem su se izjasnili o provedenom pokusu, kako im se svidjelo učenje preko Facebooka, što smatraju da je bilo učinkovito, a što ne. Ispitivanje je pokazalo da se većini učenika svidio ovaj pristup. Prosječna ocjena školskoga testa provedenoga nakon ovoga pokusa u svim razredima bila je bolja od prethodnoga. Dakle, zadovoljene su sve četiri stavke čime se smatra da je eksperiment uspio. No ovakva vrsta nastave zahtijeva veliku pripremu nastavnika i nije uvijek moguća, ali povremeno služi kao osvježenje u odnosu na inače. ${ }^{40}$

Kada je riječ o nastavi Hrvatskoga jezika, spomenut ćemo da je trenutno u tijeku natječaj za izradu videonajave za knjigu tj. book trailera koji je raspisalo Ministarstvo kulture za učenike osnovnih i srednjih škola koji bi izrađujući ga trebali primijeniti svoje znanje o filmovima i filmskim izražajnim sredstvima te scenariju iz medijske kulture. Riječ je o videouratku u trajanju od najviše tri minute kojim bi učenici trebali prikazati knjigu po želji, a koja će i druge potaknuti da je uzmu

39 Andrea Vučetić i Sergej Filipović, „Facebook - nova obrazovna platforma u nastavi povijesti“ Napredak 156 (2015), br. 3.: 319-340.

40 Vučetić i Filipović, „Facebook - nova platforma“, 319-340. 
s police. ${ }^{41}$ Spomenut ćemo i film „Sindrom $17^{442}$ koji su snimili polaznici radionice dokumentarnoga filma Škole medijske kulture učenici „Dr. Ante Peterlić“ 2016. godine. Snimili su lažni kratkometražni dokumentarni film o selu pokraj Bednje u kojemu su svi rođeni istoga datuma, 17. listopada. Navedeni film dobar je nastavni materijal pomoću kojega se učenicima može ukazati na dezinformacije i lažne vijesti.

Godine 2018. bila sam stažistica na stručnom osposobljavanju iz Hrvatskoga jezika u Osnovnoj školi „Bol“ u Splitu. Zadala sam grupni rad učenicima dvaju odjela osmih razreda zadatak da naprave film na temu „Otuđenost“ u trajanju od najviše pet minuta kako bi primijenili dotadašnje znanje iz medijske kulture. Učenicima se prijedlog zaista svidio te je ukupno osam grupa napravilo osam filmova koje smo jedan sat pregledavali, a nakon toga su na listiću sami vrednovali svoj uradak po stavkama: filmska izražajna sredstva, originalnost, kreativnost i montaža. Najbolja tri filma poslala sam na natječaj koji je raspisao Festival prvih ${ }^{43}$ te smo, nakon što ih je jedna učenica spojila u jedan i dodala neke komentare, ponovno poslali. Pozvani smo na taj festival na kojemu smo predstavljali svoju školu.

\section{Utjecaj medija na djecu: negativna praksa}

Kao što je već spomenuto, prevelika upotreba mobilnih i elektroničkih uređaja kod djece može imati negativne posljedice, poput ovisnosti, ili o internetu ili o videoigricama koji je u psihologiji definiran kao Internet Addict Disorder, a različiti su „simptomi“: osoba je potpuno zaokupljena virtualnim iskustvom; ima potrebu sve više vremena provoditi na internetu kako bi postigla željeno uzbuđenje; bezuspješno pokušava kontrolirati ili prekinuti virtualno iskustvo; osjeća uznemirenost kod pokušaja prekidanja internetske veze; na internetu ostaje puno duže nego što je u početku predvidjela; dovodi u pitanje osobne veze, posao, studij, karijeru; skriva istinu o ovisnosti pred članovima obitelji i terapeutom; ulazi u virtualni problem kako bi pobjegla od

41 Natječaj traje do 1. veljače 2020. godine, a dostupan je na: https://www.min-kulture.hr/default.aspx?id=23685 (30.12 .2019.)

42 Film je dostupan na: https://www.medijskapismenost.hr/sindrom-17-lazni-dokumentarac-uz-koji-djeca-mogu-vjezbati-kriticko-misljenje/ (30. 12. 2019.)

43 Program Festivala dostupan je na: http://www.studio-artless.hr/?q=hr/node/145 (30. 12.2019.), a o filmu možete pročitati na: http://www.studio-artless.hr/?q=hr/node/201 (30. 12. 2019.) 
problema i liječila frustracije. ${ }^{44} \mathrm{U}$ navedeno bi se mogla uklopiti ovisnost o Facebooku, a u posljednje vrijeme sve više i o Instagramu, s time da sami vlasnici tih mreža stalnim ažuriranjem i poboljšavanjem aplikacija sve više potiču ovisnost. U članku „Facebook Addiction: An Emerging Problem", Anindita Chakraborty navodi negativne posljedice korištenja Facebooka: učenici - korisnici te društvene mreže imaju slabije ocjene i provode manje vremena učeći. Upotreba te mreže njihov je najčešći oblik prokrastincije. Prevelika upotreba Facebooka ometa pravilan san. Korisnici koji do kasno u noć ostaju budni zbog Facebooka, odgađaju ustanak iz kreveta bilo radnim danom ili vikendom više od onih koji ga ne koriste u tolikoj mjeri. Facebook pruža mogućnost izgradnje lažnoga identiteta te idealne slike o sebi. Mogu i razviti mišljenje da drugi korisnici koji češće objavljuju podatke (slike, objave, statuse) na svojim profilima ili češće komentiraju druge objave, dijele ih ili stavljaju oznaku da im se „nešto sviđa“, imaju bolje živote od njih. Nasuprot tome, vjerojatnije je da oni koji imaju bogatiji društveni život, manje vremena provode na društvenim mrežama. ${ }^{45}$

Ako navedeno primijenimo na djecu školskoga uzrasta, možemo reći da zbog korištenja interneta, društvenih mreža ili videoigrica do kasnih večernjih sati djeca na nastavu dolaze umorna i neispavana, spavaju pod satovima ili su nezainteresirana za rad. Zbog sve manjeg čitanja, a sve više „scrollanja“ po ekranu, djeca imaju slabije razvijenu maštu, previše toga doslovno shvaćaju i teže razumiju pojmove koji se temelje na prenesenom značenju, poput metafore, ironije, sarkazma i frazema i to ne samo u nastavi književnosti, već općenito teško razvijaju apstraktno mišljenje i teško se koncentriraju. Zbog slabijeg čitanja, smanjuje im se opseg rječnika, a to se reflektira na njihovo usmeno i pisano izražavanje. Pojedini se ne uspijevaju odvojiti od njihovih mobilnih uređaja čak i tijekom 45 minuta školskog sata, a oduzimanje istog izaziva negativnu reakciju. Tu je i otuđenost. Djeca sve više vremena provode za ekranom nego igrajući se s prijateljima.

Osim toga, jedan od rastućih problema koji se javlja kod školske djece jest nasilje preko interneta ili tzv. „cyber bullying“. Danas se djeca sve više obračunavaju jedni s drugima preko društvenih mreža. To zna biti izrugivanje s fotografijama kolega, ali i objavljivanje slika ko-

44 Valentina Mandarić, „Novi mediji i rizično ponašanje mladih“, Bogoslovska smotra 82 (2012.), 140.

45 Anindita Chakraborty , „Facebook Addiction: An Emerging Problem“, The American Journal of Psychiatry Resident's Journal, 7-9. 
lega bez dopuštenja što je u što ima dalekosežnije posljedice jer ostaje zabilježeno zauvijek. Odnedavno to podliježe i Uredbi EU-a o zaštiti osobnih podataka zbog nepoštivanja koje mogu biti i kažnjena.

Ukratko, koliko god da nam internet omogućuje lakšu i bržu komunikaciju, brzu dostupnost podataka, koliko god da se mnogo toga može naučiti preko kanala s korisnim informacijama, roditelji bi trebali biti upoznati s kime njihova djeca komuniciraju preko internetskih mreža kako ne bi postali laka meta pedofila. Djeci ne treba braniti ni internet ni televiziju, ali je potrebno usmjeriti ih na dobre i pozitivne sadržaje kako bi korištenje medija polučilo pozitivne rezultate.

\section{Zaključak - umjerenost kao ključ odgoja za medije}

U ovom kratkom radu autorica je pokušala dati pregled odgoja za medije u hrvatskom osnovnoškolskom sustavu: kurikulumski pogled te je navela neke primjere dobre prakse. Moderno društvo donosi i promjene, a tehnologija se ubrzano razvija te je učiteljima teško pratiti sve te promjene. No to nije neizvedivo. Upotreba digitalnih medija u nastavnom procesu dobra je i poželjna ako je svrhovita i umjerena te ako će nastavnici, a u privatnom životu i roditelji, dati svojoj djeci dobar primjer. Kao što autori knjige Multimedijska didaktika kažu, a već je u radu navedeno, djeca, pa tako i odrasli, moraju naučiti planirati svoje vrijeme, ovladati tehnologijom i dozirati je, a ne postati njezini robovi. U radu su navedeni primjeri dobre prakse upotrebe Facebooka, ali i loši utjecaji te društvene mreže. Usudila bih se reći da je, u posljednje vrijeme, mlađa populacija aktivnija na mrežama kao što su WhatsApp ili Instagram, a na potonjem prevladavaju fotografije i videa te se rečenica reducira na riječi ili sintagme što opet loše utječe na razvoj jezičnih sposobnosti kod djece. Osim toga, mlađi naraštaj često će radije upotrijebiti anglizme, nego hrvatske riječi (iako postoje hrvatske riječi), upravo zbog YouTubea, Instagrama ili Facebooka. Današnji uzori postali su im youtuberi ili tzv. influenceri na Instagramu koji im pružaju pogled na svijet kakav zapravo nije, a da i ne govorimo o izloženosti međuvršnjačkom nasilju ili općenito nasilju preko ovih mreža. Sjetimo se samo primjera tuče splitskih srednjoškolki koji je završio na internetu.

Zato treba podizati svijest o tome da virtualna stvarnost nije prava, treba poticati empatiju, poštovanje prema odraslima i samopoštovanje 
kod djece, a to učitelji već godinama rade. Cilj je ovoga rada bio skrenuti pozornost na to da unatoč prednostima tehnoloških dostignuća, ne zaboravimo na jedinstvene i nezamjenjive međuljudske odnose.

\section{Bibliografija}

\section{Knjige i članci}

Anić, Vladimir, Rječnik hrvatskog jezika. Zagreb: Novi liber, 2000.

Chakraborty, Anindita, „Facebook Addiction: An Emerging Problem”, The American Journal of Psychiatry Residents' Journal, 7-9. 2017.

Mandarić, Valentina, „Novi mediji i rizično ponašanje mladih“, Bogoslovska smotra, 82 (2012), 131-149.

Marinović, Marijana, Nastava povijesti usmjerena prema ishodima učenja. Metodički priručnik za nastavnike povijesti. Zagreb: Agencija za odgoj i obrazovanje, 2014.

Matijević, Milan i Topolovčan, Tomislav, Multimedijska didaktika. Zagreb: Školska knjiga, 2017.

Medved, Siniša, „Pretpostavke za razvoj primarnog medijskog obrazovanja u Hrvatskoj“ (završni rad, Sveučilište Sjever, Sveučilišni centar Varaždin, 2015), 1-36.

Stradling, Robert, Nastava europske povijesti 20. stoljeća. Zagreb: Srednja Europa, 2005.

Vučetić, Andrea i Sergej Filipović, „Facebook - nova obrazovna platforma u nastavi Povijesti“, Napredak 156 (2015), br. 3.: 319 - 340

\section{Internetski izvori}

Festival prvih 2018. :

http://www.studio-artless.hr/?q=hr/node/145 (30.12. 2019.)

http://www.studio-artless.hr/?q=hr/node/201 (30.12. 2019.)

Film „Sindrom 17“:

https://www.medijskapismenost.hr/sindrom-17-lazni-dokumentarac-uz-koji-djeca-mogu-vjezbati-kriticko-misljenje/ (30.12.2019.)

Hrvatska enciklopedija:

http://www.enciklopedija.hr/Natuknica.aspx?ID=39755; (31. 8. 2018.)

http://www.enciklopedija.hr/natuknica.aspx?ID=39312 (31. 8. 2018.)

Javni poziv Ministarstva kulture osnovnim i srednjim školama za videonajave knjiga - učeničke radove:

https://www.min-kulture.hr/default.aspx?id=23685 (30. 12. 2019.)

Kurikulum nastavnog predmeta Hrvatski jezik za osnovne škole i gimnazije:

https://narodne-novine.nn.hr/clanci/sluzbeni/2019_01_10_215.html 
Nacionalni i okvirni kurikulum za predškolski odgoj te opće obvezno i srednjoškolsko obrazovanje (2010.):

https://www.azoo.hr/images/stories/dokumenti/Nacionalni_okvirni_kurikulum.pdf

Nastavni plan i program za osnovnu školu (2006):

http://www.azoo.hr/images/AZOO/Ravnatelji/RM/Nastavni_plan_i_program_za_ osnovnu_skolu_-_MZOS_2006_pdf

\section{SUMMARY}

This paper discusses media and gives examples of positive practise in teaching about media as well as using it in school subjects such as Croatian language and history. The author gives an overview of the 2019 curriculum regarding media education as a part of Croatian language subject in elementary schools and high schools. Readers are warned of negative influence that technology and media, especially the Internet and social networks, have on children and the development of their cognitive processes.

Keywords: media, curriculum, culture and media, internet, social networks, multimedia, Facebook 